\title{
Nitrate Reductase Activities in Lysogenic and Nonlysogenic Strains of Corynebacterium diphtheriae and Related Species
}

\author{
SHELDON B. ARDEN ${ }^{1}$ AND LANE BARKSDALE \\ Department of Microbiology, New York University Medical Center, New York, New York 10016
}

\begin{abstract}
Corynebacterium diphtheriae and closely related corynebacteria are grampositive, pleomorphic, facultatively anaerobic bacteria which have been classified (in part) according to their capacity to reduce or not reduce nitrates to nitrites. An investigation of the presence or absence of nitrate reductase activity in C. diphtheriae, in particular, and in C. belfanti, C. ulcerans, C. ovis, C. hofmanni, and C. xerosis, in general, indicates that (i) the control of the synthesis of the enzyme is a readily mutable property, (ii) enzyme synthesis occurs under anaerobic conditions, and (iii) maximal activity is associated with the "pellet" or "membrane" fraction. Additional evidence indicates that the gene $N$-red is not on the phage chromosome and, therefore, is not linked to the gene governing the synthesis of diphtherial toxin (tox) as previously claimed.
\end{abstract}

The bacterial nitrate reductases, which reduce nitrates to nitrites, serve one of two physiological functions: (i) that of nitrate assimilation in which nitrate is ultimately reduced to ammonium ion and is used as the cell's sole source of nitrogen under aerobic and anaerobic conditions, and (ii) that of nitrate respiration (dissimilation), an energy process in which nitrate is utilized in place of oxygen as the terminal electron acceptor, under anaerobic conditions. The latter process has been referred to as "nitrate or anaerobic respiration" $(8,22)$.

The capacity to reduce nitrates to nitrites has been used as a key property of Corynebacterium diphtheriae (7), separating it from a corynebacterium of ozaena, $C$. belfanti (5). It has been reported that corynebacteriophage $\beta^{\text {tox }}{ }^{+}$, when used to lysogenize $C$. belfanti, converts it to nitrate positivity $\left(\mathrm{N}-\mathrm{red}^{+}\right)$and toxinogenicity $\left(t o x^{+}\right)(11,12)$. This putative lysogenic co-conversion to two positive properties aroused our interest. Here we describe certain properties of corynebacterial nitrate reductase(s) and show that the genetic control of the synthesis of this enzyme is not linked to the gene controlling the synthesis of diphtherial toxin.

\section{MATERIALS AND METHODS}

Bacterial strains. The strains of corynebacteria used were from this laboratory, except where otherwise indicated: Corynebacterium diphtheriae, mitis, $\mathrm{C} 7_{\mathrm{s}}(-)^{t o x^{-}}$(hereafter referred to as $\left.\mathrm{C} 7\right), \mathrm{C} 7_{\mathrm{s}}(\beta)^{\text {to. }} \mathrm{t}^{+}$ (19), $\mathrm{C4}_{\mathrm{s}}(-)^{\text {tox }} \mathrm{x}^{-}(9)$ and $\mathrm{PW} 8_{\mathrm{r}}(\mathrm{P})^{\text {tox }} \mathrm{x}^{+}(16) ;$ gravis, $\mathrm{C}_{\mathrm{s}}(-)^{t o x^{-}}$(Halifax flat), $\mathrm{C}_{\mathrm{r}}(\phi)^{t a x^{+}}$(Halifax) (3); intermedius, E.B. 79 (New York University School of Medicine, The Class Collection of the Department of Microbiology) and N.S. 1057 (U.S. Armed Forces

\footnotetext{
1 Present address: Department of Pathology, Cabrini Health Care Center, New York, N.Y. 10003.
}

Institute of Pathology, Washington, D.C.); C. belfanti strains B1, B6, B8, 1170/Ore (received from Wenche Blix Gundersen; 12); 106, 107, 109 (received from N. B. Groman, University of Washington, Seattle) and 1030 (received from A. Saragea, Bucharest, Rumania; 20); C. ulcerans strains 603/50 D.L.C. (13) and 842/50 D.L.C. (27); C. ovis strains CSIR 6 (received from H. R. Carne; 7) and 21 (received from A. Saragea; 21); C. hofmanni strains ATCC 10700 and 10701 and E.B. 80 (New York University Department of Microbiology); and C. xerosis strains ATCC 373, 7094, 7711 and 9016.

Bacteriophages. Phages $\beta^{\text {tox }} x^{+}, \beta^{\text {vir toox }}{ }^{+}\left(\beta^{\text {hv64 to.x }}\right)$ and $1^{t o x} x^{+}$have been described elsewhere (14). Phage 76 c/ovis 21 , originating from a gravis strain, was received from A. Saragea (21). It is hereafter referred to as $\mathbf{Z}^{t o x^{+}}$.

Procedures for the preparation of lysogenic corynebacteria and phage stocks, phage assays, spot testing for the detection of bacteriophage, and measurement of phage adsorption were carried out as described by Holmes and Barksdale (14) and Lampidis and Barksdale (16).

Media and general methods. The compositions of the PGT medium, maltose and glucose supplements, and tryptose agars, methods of cultivation of bacteria, and the intracutaneous test for toxinogenicity have been described elsewhere $(14,16)$. Tryptoseyeast extract broth contained per liter: tryptose, 10 $\mathrm{g}$; yeast extract, $3 \mathrm{~g}$; and phenol red, $0.005 \mathrm{~g}$.

Assays for nitrate reductase activity. (i) Qualitative determination. Organisms to be screened for nitrate reductase activity were inoculated (in duplicate sets) into PGT liquid media or swabbed onto $1.5 \%(\mathrm{wt} / \mathrm{vol})$ tryptose agar each containing $0.5 \%$ (wt/vol) maltose and $0.2 \%$ (wt/vol) potassium nitrate. Tubes and plates were incubated at $37 \mathrm{C}$ for 3 to 5 days aerobically (standard incubator atmosphere) and anaerobically. Anaerobic conditions were obtained by placing the tubes and plates in a Torbal jar (model AJ-2, Torsion Balance Company, Clifton, N.J.) and flushing for 5 min with $10 \%$ carbon dioxide in nitrogen. Three pounds of gas pres- 
sure per square inch were maintained during incubation of the jar.

The product of the nitrate reductase reaction, nitrite, was assayed by the addition to the tubes or plates of a solution consisting of equal parts of sulfanilic acid ( $8 \mathrm{~g} /$ liter of $5 \mathrm{~N}$ acetic acid) and of $\alpha$ naphthylamine ( $5 \mathrm{~g} /$ liter of $5 \mathrm{~N}$ acetic acid) (29).

(ii) Quantitative determinations. When the nitrate reductase activity of a growing culture was being examined, organisms were inoculated into complete PGT medium containing $2 \%$ (wt/vol) maltose supplement and incubated at $37 \mathrm{C}$ under three different conditions: (i) aerobically in a shaking culture (300 rpm), (ii) anaerobically by continuous sparging with nitrogen, and (iii) under quasi-anaerobic conditions employing a magnetic stirrer in a stoppered bottle. Potassium nitrate at a final concentration of $0.8 \%$ (wt/vol) was added to each culture at zero time. At specific intervals $2.5-\mathrm{ml}$ samples were removed to small glass tubes and heated in a boiling water bath for 2.5 min to stop enzymatic activity. The samples were clarified by centrifugation at $1,200 \times g$ for $5 \mathrm{~min}$.

When cell-free sonic extracts or their fractions were being assayed for activity, a modification of the assay procedures of Showe and DeMoss (28) and of Ruiz-Herrera et al. (26) was used. Extracts plus $0.125 \mathrm{M}$ potassium nitrate and $1.25 \times 10^{-4} \mathrm{M}$ methyl viologen (Schwarz/Mann) were made up to a final volume of $2.4 \mathrm{ml}$ with $0.05 \mathrm{M} \mathrm{K}_{2} \mathrm{HPO}_{4}-\mathrm{KH}_{2} \mathrm{PO}_{4}$ buffer ( $\mathrm{pH} 7.3$ ) in test tubes $(1.5$ by $15 \mathrm{~cm}$ ). The tubes were flushed for $30 \mathrm{~s}$ with argon, stoppered with plastic caps, and incubated for $5 \mathrm{~min}$ at $35 \mathrm{C}$. The reaction was initiated by the quick addition of $0.1 \mathrm{ml}$ of a freshly made solution of $50 \mathrm{mg}$ of $\mathrm{Na}_{2} \mathrm{~S}_{2} \mathrm{O}_{4}$ in 10 $\mathrm{ml}$ of $0.01 \mathrm{~N} \mathrm{NaOH}$. After $10 \mathrm{~min}$ at $35 \mathrm{C}$ the reaction was terminated by vigorously shaking the mixture until the $\mathrm{Na}_{2} \mathrm{~S}_{2} \mathrm{O}_{4}$ was completely oxidized as indicated by the disappearance of the blue color of the reduced methyl viologen. Clarification was carried out as already indicated.

Nitrite content was measured by the method of Showe and DeMoss (28). To $2.5 \mathrm{ml}$ of the nitritecontaining samples, $0.75 \mathrm{ml}$ of a solution consisting of two parts of $4 \%(\mathrm{wt} / \mathrm{vol})$ sulfanilamide in $25 \%$ ( $\mathrm{vol} / \mathrm{vol}$ ) $\mathrm{HCl}$ and one part of an aqueous solution of $0.08 \%$ (wt/vol) $\mathrm{N}$-1-naphthylethylenediamine dihydrochloride was added. After $10 \mathrm{~min}$ at room temperature the absorbancy at $540 \mathrm{~nm}$ was read on a Beckman model DU spectrophotometer and determinations made using a standard curve prepared using potassium nitrite.

Nitrate reductase activity was followed in growing cultures by periodic sampling. Nitrite determinations were made on bacteria-free samples as indicated above. To ascertain the nanomoles of nitrite released per microgram of bacterial nitrogen, optical density (OD) measurements $(590 \mathrm{~nm}$, Bausch and Lomb Spectronic 20) were determined at each interval (optical density of $0.1 \approx 1.32 \times 10^{8}$ bacteria per $\mathrm{ml} \approx 5.6 \mu \mathrm{g}$ of bacterial nitrogen per $\mathrm{ml}[4]$ ).

In the case of sonic extracts or their fractions (see below), one unit of enzyme activity is defined as the amount of enzyme which will convert $1 \mu \mathrm{mol}$ of nitrate to nitrite per min. The specific activity is expressed as units of enzyme per milligram of protein (28).

Qualitative effect of $\mathrm{pH}$ and glucose on nitrate reductase activity. Duplicate cultures of $\mathrm{C} 7$ grown in complete PGT medium were centrifuged, suspended in $25 \mathrm{ml}$ of PGT plus $1 \%$ (wt/vol) glucose supplement and $0.0005 \%$ (wt/vol) phenol red (final $\mathrm{pH} 6.8$ ) to an OD of 0.5 to 1.0 in $125-\mathrm{ml}$ Erlenmeyer flasks, and incubated in a water bath shaker at $35 \mathrm{C}, 120 \mathrm{rpm}$ (quasi-anaerobiosis). As the glucose was fermented and the $\mathrm{pH}$ was lowered, potassium hydroxide was added to one flask to neutralize the acidity. At 1-h intervals, over a 7- to 8-h period, 1.5$\mathrm{ml}$ samples were removed from each flask and frozen. The samples were melted and qualitatively assayed for nitrite. In addition, $\mathrm{pH}$ values were determined on each sample with pHydrion papers (Micro Essential Laboratories, Brooklyn, N.Y.).

The effect of $\mathrm{pH}$ on nitrate reductase activity was determined by inoculating $\mathrm{C} 7$ to an $\mathrm{OD}$ of 1.0 into tryptose-yeast extract broth containing $0.5 \%$ (wt/vol) potassium nitrate unbuffered, as well as buffered with tris(hydroxymethyl)aminomethane (Tris) maleate to $\mathrm{pH} 5.5,6.3,7.1$, and 8.2 in screwcap tubes to one-half volume capacity and incubated at $37 \mathrm{C}$ (without shaking). After 1,2 , and 3 days, samples were taken and qualitatively assayed for nitrite.

Protein determinations. Protein was precipitated overnight at $4 \mathrm{C}$ from cell-free sonic extracts or their fractions by the addition of an equal volume of $10 \%(\mathrm{wt} / \mathrm{vol})$ trichloroacetic acid. Precipitates were centrifuged and washed two times in $5-\mathrm{ml}$ portions of cold $2.5 \%$ (wt/vol) trichloroacetic acid and redissolved in $0.1 \mathrm{~N} \mathrm{NaOH}$. Protein content was measured by the method of Lowry et al. (18) using bovine serum albumin as a standard

Growth and disruption of bacteria. Cultures of C. diphtheriae $\mathrm{C} 7$ were inoculated into 1-liter Erlenmeyer flasks in $800-\mathrm{ml}$ volumes containing PGT medium plus $0.5 \%$ (wt/vol) maltose and $1 \%$ (wt/vol) potassium nitrate. To maintain a low oxygen tension, the flasks were incubated as still cultures at 37 C. After 4 days the cultures were harvested, centrifuged (at $4 \mathrm{C}$ ) at $9,000 \times \mathrm{g}$ for $20 \mathrm{~min}$ and washed two times with $0.05 \mathrm{M} \mathrm{K}_{2} \mathrm{HPO}_{4}-\mathrm{KH}_{2} \mathrm{PO}_{4}$ buffer $(\mathrm{pH}$ 7.3). The packed, washed cells were resuspended in 9 to $10 \mathrm{ml}$ of the same buffer. The concentration of bacteria was always equivalent to at least $3 \mathrm{mg}$ of bacterial $\mathrm{N}$ per $\mathrm{ml}$ (4). Powdered glass beads (type 110 5005, 3M Co., St. Paul, Minn.) were added to the resuspended cells which were then subjected to sonic vibration (Sonifier Cell Disruptor, model W185, Heat Systems-Ultrasonics, Inc., Plainview, Long Island, N.Y.) in an iced container for two 2-min intervals, spaced 1 min apart. The material from disrupted cells was clarified by centrifugation at 25,000 $\times g$ for $30 \mathrm{~min}$. The supernatant was further fractionated by centrifugation at $100,000 \times g$ for $240 \mathrm{~min}$ at $4 \mathrm{C}$. Sedimented material was suspended in 0.05 $\mathrm{M} \mathrm{K}_{2} \mathrm{HPO}_{4}-\mathrm{KH}_{2} \mathrm{PO}_{4}$ buffer $(\mathrm{pH} 7.3$ ) and is referred to as the "pellet" or "membrane" fraction; the supernatant fluid is referred to as the soluble fraction.

Isolation of nitrate reductase-deficient mutants. Under anaerobic conditions the nitrate reduc. 
tases (of certain members of the Enterobacteriaceae) catalyze the reduction of nitrate to nitrite and of chlorate to chlorite. This latter product when formed in amounts lethal for the bacteria serves to select nitrate reductase-deficient mutants, because only those cells lacking this enzyme can survive under anaerobic conditions in the presence of chlorate (23).

$C$. diphtheriae strains $\mathrm{C} 7$ and $\mathrm{C} 7(\beta)$ were plated out onto tryptose agar containing $0.5 \%$ (wt/vol) potassium nitrate and 0.2 to $0.5 \mathrm{M}$ potassium chlorate and incubated at $37 \mathrm{C}$ for 5 days under anaerobic conditions. The plates were incubated aerobically for an additional 2 to 3 days to allow the colonies to increase in size. Isolated colonies were picked and tested for nitrate-reducing activity.

In addition to this procedure, $N$-red $d^{-}$mutants of C7 were obtained by treatment with $N$-methyl- $N$ nitroso- $N^{\prime}$-nitroguanidine ( $\mathrm{K}$ and $\mathrm{K}$ Laboratories, Plainview, N.Y.). An overnight culture of $\mathrm{C} 7$ was subcultured into complete PGT medium to an OD of 0.1 to 0.2 and grown up to approximately $8 \times 10^{8}$ cells $/ \mathrm{ml}(\mathrm{OD} \approx 0.6)$. A $10-\mathrm{ml}$ volume of culture was centrifuged, washed once in $10 \mathrm{ml}$ of special Trismaleate buffer (T-M), pH 6.0 (1), resuspended in 10 $\mathrm{ml}$ of T-M buffer containing 100 to $300 \mu \mathrm{g}$ of NTG per $\mathrm{ml}$, and incubated for $15 \mathrm{~min}$, at $35 \mathrm{C}$, and at 200 rpm. The treated culture was then centrifuged ( $4 \mathrm{C}$ ), washed once in cold T-M buffer, and suspended in saline to an OD of 0.5 . These cells were serially diluted, plated out onto tryptose agar (plus or minus potassium chlorate), and incubated anaerobically as above. Isolated colonies were scored for nitrate reductase activity. Selected mutants were cloned and retained for further study.

\section{RESULTS}

Nitrate reductase activity among species of Corynebacterium. Twenty-six strains of Corynebacterium examined under aerobic and anaerobic conditions with regard to nitrate reductase activities are listed in Table 1. All seven Corynebacterium diphtheriae strains tested, mitis, gravis, and intermedius, as well as $C$. hofmanni strains and two strains of $C$. xerosis, showed strong activity anaerobically and weak (to moderate) activity aerobically, whereas two strains each of $C$. ulcerans, $C$. ovis, and $C$. xerosis and eight $C$. belfanti strains were negative under both sets of conditions.

Corynebacterial nitrate reductase. When C7 $(-)^{t o x^{-} N-\text { red }^{+}}$was grown in complete PGT medium containing $0.8 \%(\mathrm{wt} / \mathrm{vol})$ potassium nitrate and incubated (i) aerobically in a shaking culture (300 rpm), (ii) anaerobically by continuous sparging with nitrogen, and (iii) employing a magnetic stirrer in a stoppered bottle under quasi-anaerobic conditions, the greatest amount of nitrate reductase activity was found under conditions of reduced oxygen tension (conditions ii and iii) (Fig. 1).

It has been reported that when glucose is used as a carbon source for Citrobacter sp. nitrate reductase activity is repressed (15). Preliminary tests with glucose and maltose indi-

TABLE 1. Nitrate reductase activity of various corynebacterial "species" a

\begin{tabular}{|c|c|c|}
\hline \multirow{2}{*}{ Bacterial strains } & \multicolumn{2}{|c|}{ Nitrate reductase activity } \\
\hline & Aerobic $^{b}$ & Anaerobic $^{b}$ \\
\hline \multicolumn{3}{|l|}{ Corynebacterium diphtheriae } \\
\hline $\begin{array}{l}\mathrm{C} 7_{\mathrm{s}}(-)^{\operatorname{tox}-}, \mathrm{C}_{\mathrm{s}}(\beta)^{t o x+}, \mathrm{PW} 8_{\mathrm{r}}(\mathrm{P})^{t o x+} \\
\text { gravis }\end{array}$ & Weak to moderate & Strong \\
\hline $\begin{array}{l}\mathrm{C} 8_{\mathrm{s}}(-)^{t o x-}, \mathrm{C} 8_{\mathrm{r}}(\phi)^{t o x+} \\
\text { intermedius }\end{array}$ & Weak to moderate & Strong \\
\hline E.B. 79, NS 1057 & Weak to moderate & Strong \\
\hline $\begin{array}{l}\text { C. ulcerans } \\
603 / 50,842 / 50\end{array}$ & Negative & Negative \\
\hline $\begin{array}{l}\text { C. ovis } \\
\text { 21, CSIR } 6\end{array}$ & Negative & Negative \\
\hline B1, B6, B8, 1170/Ore, 106, 107, 109, 1030 & Negative & Negative \\
\hline $\begin{array}{l}\text { C. xerosis } \\
9016,373 \\
7094,7711\end{array}$ & $\begin{array}{l}\text { Weak to moderate } \\
\text { Negative }\end{array}$ & $\begin{array}{l}\text { Strong } \\
\text { Negative }\end{array}$ \\
\hline $\begin{array}{l}\text { C. hofmanni } \\
\quad 10700,10701 \text {, E.B. } 80\end{array}$ & Weak to moderate & Strong \\
\hline
\end{tabular}

a Qualitative nitrate reductase activity was determined by the intensity of the reddish color formed as a result of the diazo-coupling reagents added. Negative, no color change; weak, pink; moderate, red; strong, dark reddish-brown.

${ }^{b}$ Condition of growth. 


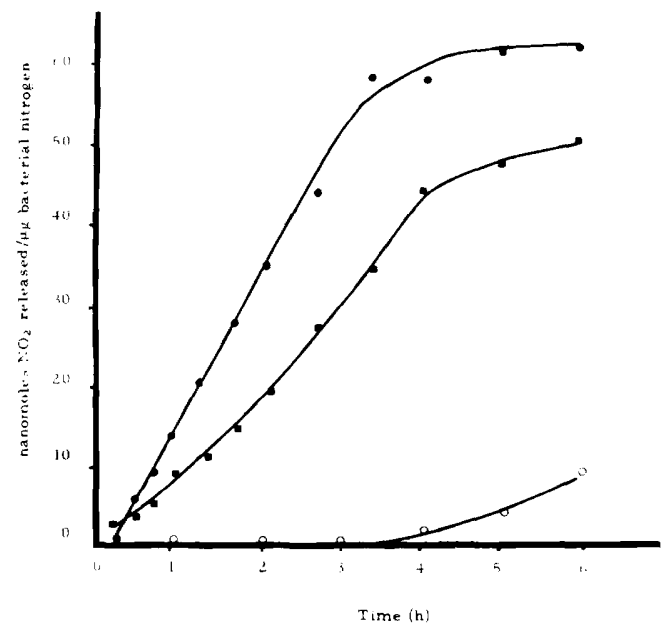

FIG. 1. Reduction of nitrate by $C 7_{s}(-)^{t o x^{-} N-r_{e d}{ }^{+}}$ grown at $37 \mathrm{C}$ under three different conditions of incubation: (i) aerobically in a shaking culture $(300$ rpm), $\bigcirc$; (ii) anaerobically by continuous sparging with nitrogen, $\mathbf{\square}$; and (iii) under quasi-anaerobic conditions employing a magnetic stirrer in a stoppered bottle,

cated that much less nitrate reductase activity was associated with glucose-grown cells. However, the final $\mathrm{pH}$ of the medium of the glucosegrown cells was 5.5 or lower. C7 grown in PGT medium containing $0.5 \%(\mathrm{wt} / \mathrm{vol})$ potassium nitrate and $1 \%$ (wt/vol) glucose (under quasi-anaerobic conditions) and continually neutralized with potassium hydroxide showed nitrate reductase activity qualitatively similar to that produced by maltose-grown cells (Tables 2 and 3 ). In the unneutralized glucose-containing culture, the $\mathrm{pH}$ fell to 5.5 and there was negligible activity.

Maximal activity in the tryptose-yeast extract-nitrate broth was observed with the unbuffered culture as well as the cultures buffered at $\mathrm{pH} 7.1$ and 8.2 ; a slightly decreased activity was observed at $\mathrm{pH} 6.3$; and negligible activity was observed at $\mathrm{pH} 5.5$.

When the specific nitrate reductase activity of a whole-cell sonic extract of strain $\mathrm{C} 7(-)^{t o x-N-r e d^{+}}$and that of the soluble (supernatant) and "pellet" or "membrane" fractions were compared, about $25 \%$ of the original activity remained in the soluble fraction (see Table 4). Thus, the major nitrate reductase activity appears to be located in the "pellet" or "membrane" fraction of $C$. diphtheriae $\mathrm{C} 7$.

Lysogenization of $\mathrm{N}^{- \text {red }^{-}}$corynebacteria. When the nitrate reductase-negative mutant $\mathrm{C} 7(-)^{t o x^{-} N-\text { red }^{-}}$was lysogenized with $\beta^{t o x^{+}}\left(1^{t o x^{+}}\right.$ or $\mathrm{Z}^{\text {to. }} x^{+}$), it became a toxin producer but re- tained its $\mathrm{N}$-red $d^{-}$character. $\mathrm{N}$-red $\mathrm{d}^{-}$mutants of C7 $(\beta)^{t o x^{+}}$were still lysogenic and maintained their tox ${ }^{+}$status (Fig. 2).

TABLE 2. Effect of glucose and maltose on $p H$ and on yields (qualitative) of nitrate reductase ${ }^{a}$

\begin{tabular}{|c|c|c|c|c|}
\hline $\begin{array}{c}\text { Sugar } \\
\text { supple- } \\
\text { ment }\end{array}$ & Initial pH & $\begin{array}{c}\text { Periodic } \\
\text { neutraliza- } \\
\text { tion with } \\
\mathrm{KOH}\end{array}$ & Final $\mathrm{pH}$ & $\begin{array}{c}\text { Nitrate re- } \\
\text { ductase ac- } \\
\text { tivity (at } 8 \\
\text { h) }\end{array}$ \\
\hline Glucose & 6.85 & - & 5.5 & Negligible \\
\hline Glucose & 6.85 & + & $6.8-7.0$ & Strong \\
\hline Maltose & 6.85 & - & $6.6-6.8$ & Strong \\
\hline
\end{tabular}

${ }^{a} \mathrm{C} 7$ cells were inoculated to an $\mathrm{OD}$ of 1.0 into PGT medium containing $0.5 \%$ (wt/vol) $\mathrm{KNO}_{3}$ supplemented with $1.0 \%$ (wt/vol) sugar and incubated under quasi-anaerobic conditions in a $37 \mathrm{C}$ water bath at $120 \mathrm{rpm}$. One glucose-containing culture was periodically neutralized with $\mathrm{KOH}$. The $\mathrm{pH}$ of each culture was determined at 0 and $8 \mathrm{~h}$. Nitrate reductase activity was qualitatively determined at $8 \mathrm{~h}$ and scored as in Table 1.

TABLE 3. Effect of $p H$ on yields (qualitative) of nitrate reductase ${ }^{a}$

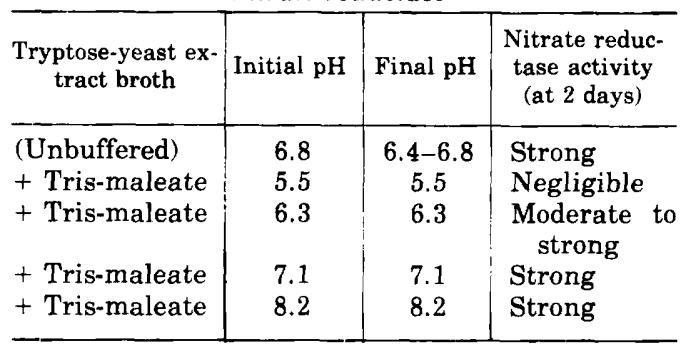

${ }^{a} \mathrm{C} 7$ cells were inoculated to an $\mathrm{OD}$ of 1.0 into tryptose-yeast extract broths containing $0.5 \%$ (wt/vol) $\mathrm{KNO}_{3}$, unbuffered, and buffered with Trismaleate $(0.05 \mathrm{M}): \mathrm{NaOH}$ to $\mathrm{pH} 5.5,6.3,7.1$, and 8.2 and incubated as still cultures at $37 \mathrm{C}$. The $\mathrm{pH}$ of each culture was determined at 0 and 2 days. $\mathrm{Ni}$ trate reductase activity was qualitatively determined at 2 days and scored as in Table 1.

TABLE 4. Localization of nitrate reductase activity in fractions of a cell-free sonic extract of Corynebacterium diphtheriae strain C7

\begin{tabular}{lc}
\hline \multicolumn{1}{c}{ Determination } & $\begin{array}{c}\mathrm{Sp} \mathrm{act}^{2} \\
\left(\times 10^{-3}\right)\end{array}$ \\
\hline Extract from sonically disrupted $C$. & \\
$\quad$ diphtheriae C7 ............... & 0.746 \\
Soluble (supernatant) fraction ..... & 0.182 \\
"Pellet" or "membrane" fraction . . . & 1.348 \\
\hline
\end{tabular}

a Specific activity is defined as enzyme units per milligram of protein. One enzyme unit is defined as the amount of enzyme which will convert 1 $\mu \mathrm{mol}$ of nitrate to nitrite per min. Electron micrographic monitorings of the soluble fraction and the "pellet" fraction comprise Fig. 4. 
Two other tox-, N-red- corynebacteria, $C$. ulcerans 603 and $C$. belfanti 1030 when lysogenized with $\beta^{\text {tox }}{ }^{+}$gained the capacity to synthesize diphtherial toxin but remained $N$-red $d^{-}$. C. ovis $\left(\mathrm{N}\right.$-red $\left.{ }^{-}\right)$, strain 21 , was not sensitive to phage $\beta^{\text {tox }}+$ but could be lysogenized with phage $\mathrm{Z}^{\text {tox }}{ }^{+}$. Strain $21(\mathrm{Z})^{t o x^{+}}$was still $N$-red ${ }^{-}$. Thus, although lysogenicity was followed in each of these four cases by conversion to toxinogenicity, there was no change in the inability to reduce nitrates to nitrites (Fig. 3 ).

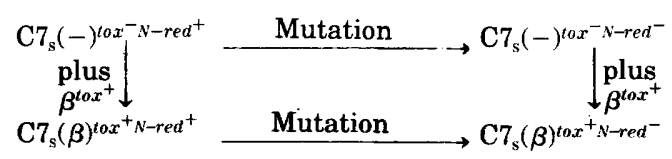

FIG. 2. Established bacterial genomes which indicate that tox ${ }^{+}$and $\mathrm{N}$-red ${ }^{+}$are separate and independent.
Adsorption to, but not lysis of, C. belfanti strains by phage $\beta^{t o x}{ }^{\top}$. Although seven $C$. belfanti strains were capable of removing $\beta^{t o x^{+}}$ phage particles in a standard adsorption experiment with an efficiency sometimes equalling that of the $\mathrm{C} 7$ reference strain, they were incapable of supporting the growth of the three tox ${ }^{+}$ corynebacteriophages $\beta, \beta^{\text {vir }}$ and 1 , either in soft agar overlays on plates or during continuous subculture in the presence of excess phage (Table 5).

\section{DISCUSSION}

Our initial studies concerning the presence of the anaerobic nitrate reductase were in relation to the proposed linkage of the gene controlling its synthesis to the corynebacteriophage gene, tox, which governs the synthesis of diphtherial

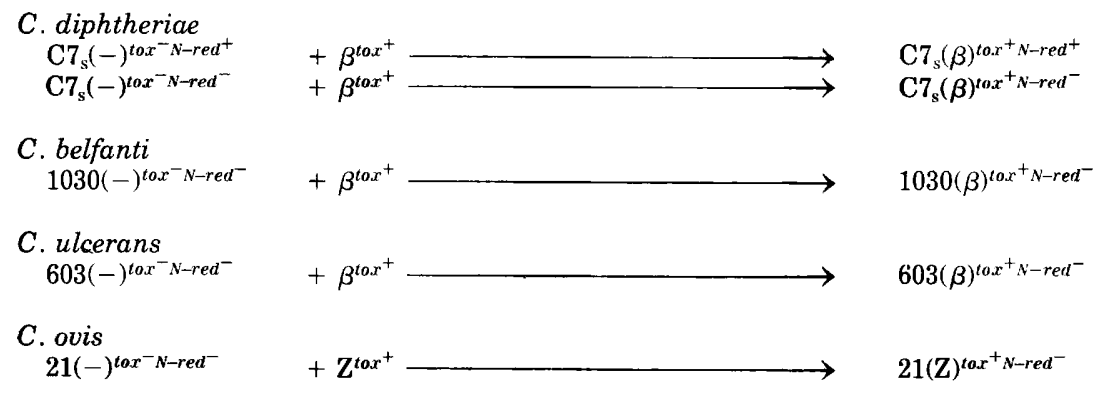

Fig. 3. Expression of tox ${ }^{+}$in relation to $N$-red ${ }^{+}$in four corynebacterial "species."

TABLE 5. Behavior of C. belfanti, C. diphtheriae, and C. ulcerans in the presence of various concentrations of corynebacteriophages ${ }^{a}$

\begin{tabular}{|c|c|c|c|c|}
\hline \multirow[t]{2}{*}{ Strain } & \multicolumn{2}{|c|}{ Lysis by drops $\underset{\beta^{u r r}, 1}{(0.05 \mathrm{ml}) \text { of phages } \beta,}$} & \multirow{2}{*}{$\begin{array}{c}\text { Formation of } \\
\text { plaques by } \beta, \\
\beta^{v i r}, 1 \text { (replicates } \\
\text { in) }\end{array}$} & \multirow{2}{*}{$\begin{array}{l}\text { Efficiency of ad } \\
\text { sorption of } \beta^{\text {toxt }}\end{array}$} \\
\hline & $5 \times 10^{9} \mathrm{PFU} / \mathrm{ml}$ & $1 \times 10^{6} \mathrm{PFU} / \mathrm{ml}$ & & \\
\hline \multicolumn{5}{|l|}{ C. belfanti ${ }^{b}$} \\
\hline Strain B-1 & + & - & - & 0.9 \\
\hline B- 6 & + & - & - & 1.0 \\
\hline B-8 & + & - & - & 0.9 \\
\hline 1170/Ore & + & - & - & 0.8 \\
\hline 106 & + & - & - & 1.0 \\
\hline 107 & + & - & - & 1.0 \\
\hline 109 & + & - & - & 1.0 \\
\hline \multicolumn{5}{|l|}{ C. diphtheriae } \\
\hline Strain $\mathrm{C}_{\mathrm{s}}(-)^{t o x} x^{-} c$ & + & + & + & 1.0 \\
\hline $\mathrm{C} 4_{\mathrm{s}}(-)^{t o x^{-}}$ & + & + & + & 1.1 \\
\hline \multicolumn{5}{|l|}{ C. ulcerans } \\
\hline Strain 603 & + & + & + & 0.6 \\
\hline
\end{tabular}

a PFU, Plaque-forming units; +, lysis; -, no lysis.

'Strains of $C$. belfanti undergo lysis from without (first two columns), but do not support phage replication (column 3). The enzymatic, nonproductive lysis which is observed results from the action of murolytic enzymes in the phage stocks.

$c$ Standard reference strain, $\mathrm{C}_{\mathrm{s}}(-)^{t o x^{-}}$, which adsorbs $\beta^{t o x^{+}}$phage with an efficiency of 1.0. 

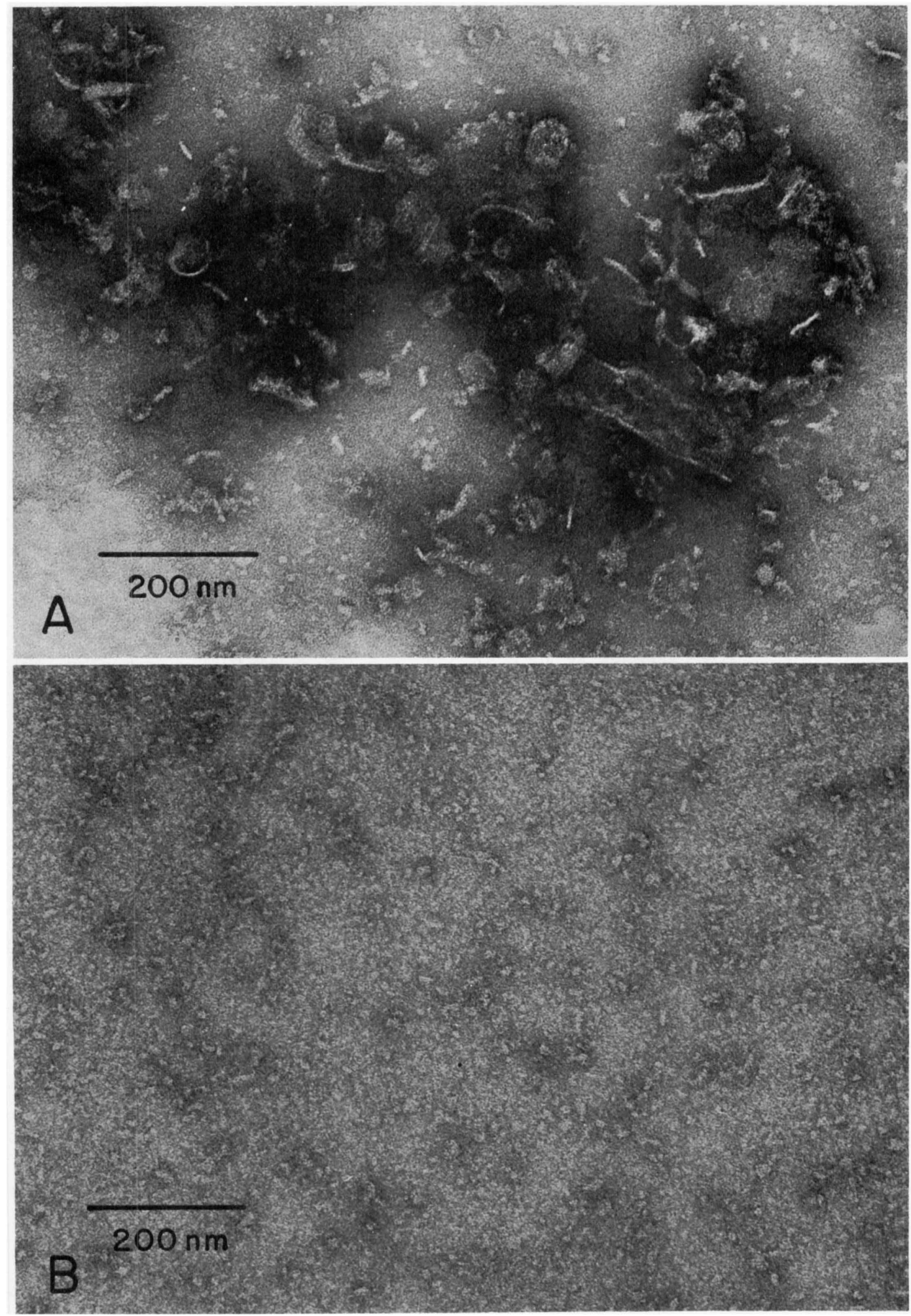

FIG. 4. Electron micrographs (prepared by K. S. Kim) of a bacteria-free sonic extract ("pellet" and soluble fractions) of Corynebacterium diphtheriae $\mathrm{C}_{s}(-)^{t o x^{-} \mathrm{N}-\text { red }} \mathrm{f}^{+}$negatively stained with $2 \%$ (wt/vol) ammonium molybdate. (A) $100,000 \times \mathrm{g}$ "pellet" fraction consisting mostly of small membrane fragments associated with major nitrate reductase activity. (B) $100,000 \times \mathrm{g}$ soluble (supernatant) fraction consisting mostly of ribosomelike particles $( \pm 15 \mathrm{~nm}$ in diameter). There are no bacterial cell membrane structures. See text concerning residual activity associated with this soluble fraction. 
toxin. If this linkage existed, one would expect that phage $\beta^{t . x^{+}}$would co-convert a nontoxinogenic $\left(t o x^{-}\right)$, nitrate reductase-deficient $(N$ $\mathrm{red}^{-}$) corynebacterium to the ability to synthesize both diphtherial toxin and nitrate reductase. Two independent investigations employing a number of strains of the $N$-red-Corynebacterium belfanti, plus phage $\beta^{\text {tox }} x^{+}$, purportedly achieved this co-conversion in one of two ways: (i) by infecting strains with high multiplicities of $\beta$ or (ii) following continuous subculture of $C$. belfanti in the presence of this same phage (17, 19; personal communication to $\mathrm{L}$. B. from N. B. Groman, 1964). The $N$-red $d^{-}$strains $C$. ulcerans $603, C$. belfanti 1030 , and a $C$. diphtheriae $\mathrm{C} 7$ mutant are to $x^{-}$and sensitive to phage $\beta^{\text {tox }}+$. The N-red $d^{-}$tox- C. ovis, strain 21 , is sensitive to phage $\mathrm{Z}^{\text {tox }}{ }^{+}$. Lysogenic strains prepared from each of the foregoing corynebacteria and corynebacteriophages were all tox ${ }^{+}$and $N$ red $^{-}$(Fig. 3). There seems, then, no correlation between the presence of a tox ${ }^{+}$prophage and the capacity to reduce nitrates. Were there such a correlation, the converted $\mathrm{N}$-red ${ }^{+}$strains would be heterogenotes since the nonlysogenic strains independently undergo mutation with regard to nitrate reductase activity.

Through further investigation of the corynebacterial nitrate reductase, in particular that of C. diphtheriae strain $\mathrm{C} 7$, we have shown that it is membrane associated. It has also been observed that its activity is "repressed" when cells are grown in the presence of glucose. This is actually a pH effect since it can be obtained by growing $\mathrm{C} 7$ in a medium having a $\mathrm{pH}$ of 5.5 or below. Whereas a drop in $\mathrm{pH}$ is always associated with glucose-grown cells, continuous neutralization of them with putassium hydroxide leads to the formation of reasonable amounts of enzyme. It appears that the corynebacterial nitrate reductase is a dissimilatory one since (i) the media being used contain organic nitrogen sources, and one would expect these to be preferentially utilized to the inorganic nitrogen source (potassium nitrate), and (ii) maximal activity is observed under conditions of anaerobiosis or reduced oxygen tension.

The capacity to reduce nitrates was early exploited as a character useful in the taxonomy of corynebacteria (6) and mycobacteria (32). In Escherichia coli the nitrate reductase complex appears to be controlled by several genetic loci (10). Nothing is known about the genetic control of nitrate reductase in Corynebacterium. The mutation from $N$-red ${ }^{+}$to $\mathrm{N}_{\text {-red }}{ }^{-}$is not uncommon. Yet, somehow in nature it does not occur very frequently or there would be more reports of isolates of $C$. diphtheriae which lack the activity. In bacterial taxonomy, trivial prop- erties can often be successfully exploited because mutations in them or affecting their expression are selected against in the natural environment. An example in kind is the usefulness of $l a c^{-}$in the characterization of Shigella dysenteriae and Shigella sonnei. Both organisms carry the $Z$ gene controlling the synthesis of $\beta$-galactosidase but lack entirely the $E$. coli permease $(17,25)$. In the laboratory, mutants which are $\mathrm{lac}^{+}$are easily obtained. Yet these mutants are often susceptible to such counter-selecting agents as bacteriophages and seem never to be isolated from the wild. In the case of $C$. diphtheriae in the wild there may be a special advantage to being able to turn on nitrate respiration with the result that selective pressures strongly favor $\mathrm{N}$-red ${ }^{+}$strains. This would especially be the case if, as is true for a number of gram-negative bacteria $(2,24$, 30,31 , nitrate respiration in corynebacteria were cofunctional with certain other essential reductases.

\section{ACKNOWLEDGMENTS}

This work was supported by Public Health Service grant AI-01071 from the National Institute of Allergy and Infectious Diseases.

We are grateful to K. S. Kim and Edward Goldzimer for aid in carrying out these studies and to Geraldine Hodgson for help with this manuscript.

\section{REPRINT REQUESTS}

Address reprint requests to : Dr. Lane Barksdale, Dept. of Microbiology, New York University Medical Center, 550 First Ave., New York, N.Y. 10016.

\section{LITERATURE CITED}

1. Adelberg, E. A., M. Mandel, and G. C. C. Chen. 1965. Optimal conditions for mutagenesis by N-methyl-N'nitro-N-nitrosoguanidine in Escherichia coli. Biochem. Biophys. Res. Commun. 18:788-795.

2. Azoulay, E., J. Puig, and F. Pichinoty. 1967. Alteration of respiratory particles by mutation in Escherichia coli. Biochem. Biophys. Res. Commun. 27:270-274.

3. Barksdale, L. 1959. Symposium on the biology of cells modified by viruses or antigens. I. Lysogenic conversions in bacteria. Bacteriol. Rev. 23:202-212.

4. Barksdale, W. L., and A. M. Pappenheimer, Jr. 1954. Phage-host relationships in nontoxigenic and toxigenic diphtheria bacilli. J. Bacteriol. 67:220-232.

5. Bezjak, V. 1954. Differentiation of Corynebacterium diphtheriae of the mitis type found in diphtheria and ozaena. I. Biochemical properties. Antonie van Leeuwenhoek J. Microbiol. Serol. 20:269-272.

6. Buchanan, R. E., and N. E. Gibbons. 1974. Bergey's manual of determinative bacteriology, 8th ed., p. 601 . Williams and Wilkins, Co., Baltimore.

7. Carne, H. R. 1939. A bacteriological study of 134 strains of Corynebacterium ovis. J. Pathol. Bacteriol. 49:313328.

8. Egami, F. 1973. A comment to the concept on the role of nitrate fermentation and nitrate respiration in an evolutionary pathway of energy metabolism. Z. Allg. Mikrobiol. 13:177-181.

9. Freeman, V. J. 1951. Studies on the virulence of bacteriophage-infecting strains of Corynebacterium diphtheriae. J. Bacteriol. 61:675-688. 
10. Glaser, J. H., and J. A. De Moss. 1972. Comparison of nitrate reductase mutants of Escherichia coli selected by alternative methods. Mol. Gen. Genet. 116:1-10.

11. Groman, N. B. 1960 . Conversion by bacteriophage-a factor in bacterial variation, p. 41-46. In J. D. Dawson and L. W. Parks (ed.), Proceedings of the twentyfirst annual biology colloquium. Microbial genetics. Oregon State College, Office of Publications, Corvallis, Oregon.

12. Gundersen, W. B., and S. D. Henriksen. 1959. Conversion in Corynebacterium belfanti by means of a temperate bacteriophage originating from a toxigenic strain of Corynebacterium diphtheriae, type mitis. Acta Pathol. Microbiol. Scand. 47:173-181.

13. Henriksen, S. D., and R. Grelland. 1952. Toxigenicity, serological reactions and relationships of the diphtheria-like corynebacteria. J. Pathol. Bacteriol. 64:503511.

14. Holmes, R. K., and L. Barksdale. 1969. Genetic analysis of tox ${ }^{+}$and tox $x^{-}$bacteriophages of Corynebacterium diphtheriae. J. Virol. 3:586-598.

15. Kapralek, F., J. Dolezal, and I. Drahonovska. 1973. Effect of glucose on the synthesis of bacterial respiratory nitrate reductase and tetrathionate reductase. Folia Microbiol. (Prague) 18:1-6.

16. Lampidis, T., and L. Barksdale. 1971. Park Williams number 8 strain of Corynebacterium diphtheriae. J. Bacteriol. 105:77-85.

17. Li, K., L. Barksdale, and L. Garmise. 1961. Phenotypic alterations associated with the bacteriophage carrier state of Shigella dysenteriae. J. Gen. Microbiol. 234:355-367.

18. Lowry, O. H., N. J. Rosebrough, A. L. Farr, and R. J. Randall. 1951. Protein measurement with Folin phenol reagent. J. Biol. Chem. 193:265-275.

19. Matsuda, M., and L. Barksdale. 1967. System for the investigation of the bacteriophage-directed synthesis of diphtherial toxin. J. Bacteriol. 93:722-730.

20. Maximescu, P. 1968. New host strains for the lysogenic Corynebacterium diphtheriae Park Williams no. 8 strain. J. Gen. Microbiol. 53:125-133.

21. Maximescu, P., A. Pop, A. Oprisan, and E. Potorac. 1968. Relations biologiques entre Corynebacterium ul- cerans, Corynebacterium ovis et Corynebacterium diphtheriae. Arch. Roum. Pathol. Exp. Microbiol. 27:733-750.

22. Nason, A. 1962. Symposium on metabolism of inorganic compounds. II. Enzymatic pathways of nitrate, nitrite, and hydroxylamine metabolism. Bacteriol. Rev. 26:16-41.

23. Pichinoty, F., J. Puig, M. Chippaux, J. Bigliardi-Rouvier, and J. Gendre. 1969. Recherches sur des mutants bacteriens ayant perdu les activites catalytiques liees a la nitrate reductase $\mathbf{A}$. II. Comportement envers le chlorate et le chlorite. Ann. Inst. Pasteur Paris 116:409-432.

24. Piechaud, M., J. Puig, F. Pichinoty, E. Azoulay, and L. Le Minor. 1967. Mutations affectant la nitrate-reductase $A$ et d'autres enzymes bacteriennes d'oxydoreduction. Etude preliminaire. Ann. Inst. Pasteur Paris 112:24-37.

25. Rickenberg, H. V. 1960 . Occurrence of $\beta$-galactosidase in the genus Shigella. J. Bacteriol. 80:421-422.

26. Ruiz-Herrera, J., M. K. Showe, and J. A. De Moss. 1969. Nitrate reductase complex of Escherichia coli $\mathrm{K} 12$ : isolation and characterization of mutants unable to reduce nitrate. J. Bacteriol. 97:1291-1297.

27. Saxholm, R. 1951. Toxin-producing diphtheria-like organisms isolated from cases of sore throat. J. Pathol. Bacteriol. 63:303-311.

28. Showe, M. K., and J. A. DeMoss. 1968. Localization and regulation of synthesis of nitrate reductase in Escherichia coli. J. Bacteriol. 95:1305-1313.

29. Society of American Bacteriologists. 1957. Manual of microbiological methods, p. 153-154. McGraw-Hill, New York.

30. Stouthamer, A. H. 1967. Nitrate reduction in Aerobacter aerogenes. II. Characterization of mutants blocked in the reduction of nitrate and chlorate. Arch. Mikrobiol. 56:76-80.

31. Stouthamer, A. H. 1969. A genetical and biochemical study of chlorate resistant mutants of Salmonella typhimurium. Antonie van Leeuwenhoek J. Microbiol. Serol. 35:505-521.

32. Virtanen, S. 1960 . A study of nitrate reduction by mycobacteria. Acta Tuberc. Scand. Suppl. 47:1-119. 